\title{
Netting Impact on a Corporate Finance Management
}

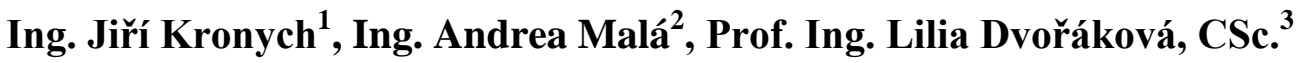

Faculty of Economics, University of West Bohemia, Czech Republic, Univerzitní 22, 30614 Plzeň

\begin{abstract}
The study presents result of the research in the field of financial system, specifically netting model in the context of the 21 st century. Actuality of netting management is an integration into the system of strategic and operational management of the company and now it is caused by the need to ensure a long-term sustainable financial position and performance of the company in the conditions of the dissected national and international market. Financial systems bring new concept to the company that helps to reduce costs connected with extra work that should be done without these systems.

On the base of the qualitative research results the introduction of netting was presented and the types of netting were introduced. The results coming from the quantitative research include the netting model in an international company and whole entities connected with the company. The draft includes identification, analysis, evaluation and formulation of the specific netting model. The data were obtained from the financial department of the company and were modified, because of the strategic aspect, but the modification reflects the reality.
\end{abstract}

Integration and utilisation of netting model present the way how to effectively manage financial process in the conditions of the $21^{\text {st }}$ century.

Keywords: Liabilites / Netting / Payments / Receivables / Revenues.

\section{INTRODUCTION}

All the basics of financial management come and are born in large companies, where the part of the financial management is to optimize the processes to bring enterprise-saving time, financial, human resources and others. Any optimization processes that companies use, can be associated with a theory Kaizen, when companies try to optimize their processes in the long term and thus reduce their costs. Kaizen includes a long-term strategy, which should be known to all responsible employees in the system. The authors in the paper make theoretical introduction to finance management. For the purpose of the contribution netting, as the part of the financial management was selected. Since the financial management constitute a long chapter, the contribution will be focused on this area.

Within this area complete netting model will be proposed in a selected company. This model will be introduced and described together with proposals for each netting rules. The whole netting model will be finally evaluated. Netting hides great potential for international companies and provides time savings, removes the administrative routines and with a reduction of payments brings clarity in international complex operations.

\section{Problem Formulation and Methodology}

Complex system of multinational corporations, particularly settlement of payments between the entities renders the question of different systems that simplify this complex mechanism, makes it transparent and brings savings to businesses in the form of time, money and administrative costs.

The results presented in the paper are based on qualitative research literary and electronically processed sources of authors coming from the academic sphere as well as the practice. Namely they are primarily monographic publications, research reports, professional studies, papers and review articles in professional journals published in relation to the topic of financial and economic management and system in the worldwide context, focused on netting (Brealey, 2014; Cooper, 2004; Madura, 2012).

The target of the quantitative research was identification, analysis, evaluation and formulation of the draft for the netting model. The empiric data were obtained by a questionnaire survey in a financial department of the company. 


\section{NetTing - A Theoretical Basis}

It is a method that is used in large transnational companies. Netting principle consists the settlement of receivables and payables in a different ways of netting.

The main purpose of netting for large companies is to reduce transaction costs, due to the settlement of receivables and payables, so the company does not have to proceed a large number of transactions, but only the transactions that are required to comply with overall assets and liabilities. [5], [1], [2]

\section{Types of netting}

In a netting process, there are several types of netting. The types are sorted out according the number of parties in a netting model or according the complexity of the model itself

\section{Payment netting}

This is a summation type of netting. Summarization, because each party in a given period summarizes the amount to be paid. The second part recieves only difference of values, as one settlement payment of the receivable or liability. [5]

The main advantage of the payment netting is to reduce settlement risk through the payment reduction. It is also applied, in order to limit the credit risk that causes foreign exchange losses

\section{Close-Out Netting}

For this type of netting it is typical that reduces risks before netting launch. Close-Out Netting is used in situations where participating counterparties have several commitments which, are overdue and going to be settled. [4]

\section{Bilateral netting}

The purpose lies in the fact that two companies contractually agree that they will nett payments between themselves. The companies sign a major contract that specifies the type of netting and also future contracts that will be affected. Bilateral netting is typical for the OTC derivatives markets. [3]

\section{Multilateral netting}

It covers more subjects, which have reciprocal links among them. The main pros of multilateral netting is that it considerably reduces the interactions, significantly reduces credit risk than bilateral netting. For proper operation of multilateral, netting center and coordinator must be included. [6]

The aim of this chapter is to propose a netting model that could company implement in its interbranch payments. Netting model will be proposed from the perspective company branch. Such a model could be implemented in any other branches. From the position of company branch XY the payments will be made with offices in China, Bulgaria, USA and Mexico. Company XY will therefore monitor China's currency in the Chinese CNY (Chinese yuan), for Bulgaria is considered currency EUR, for USA USD (US dollar), and for Mexico is also USD. In company XY will be considered business currency EUR, but for the Czech accounting, company will lead the Czech currency CZK.

Operations in netting model must be divided according to individual follow-up actions that must be done before the netting. After this step, netting could take place without any problems.

This includes the following actions:

- Payment confirmation for the period covered by the netting and the exposure of the netting draft. This operation should be done week before the netting.

- Upload the information contained in the invoices to the accounting system. It is considered to be sufficient to upload the information into the system 12 hours before netting itself.

- Validation of all uploaded information in accounting system by the authorized person. Once the information is uploaded into the system, it is necessary to validate them immediately.

- Make netting and distribute the final calculation after netting to all interested parties.

- Follow the payment order after netting, a net amount after netting - payables and receivables are settled. 
A fundamental rule that must be fulfilled is to respect the timing (dates and time). Data needed for netting must be prepared in regular predetermined time intervals.

Before coming to the point one, confirmation of all payments in a given period, it is necessary to have these receivables and liabilities uploaded in the accounting system.

The proposal of netting payments itself should be ready after confirmation of all payments and should include:

- Document identification - determined by the exact number.

- Variable symbol - labeled by the order of the netting payments.

- The amount that will be paid.

- Payment currency.

- The company, which has to be paid.

Such a proposal of netting payments should be sent to controlling center to be verified and approved. Now it is necessary to determine when the actual netting payments take place. After considering all the consequences in the company, it would be appropriate to set up every last Thursday of the month for netting. This date was chosen intentionally, because every Tuesday company generates MRP (material requirment planning) and therefore all orders are sent on Tuesday. On Wednesday the confirmation comes and subsequent invoice is done. Thus on Thursday everything is ready for the final netting. The end of the month was chosen as the most appropriate date, however the first week of each month company handles the payroll and then following payroll payments and therefore it could lead to congestion of whole model.

\section{Draft of the Netting Payments}

Part of the netting process is as invoices payment as receiving payments from invoices issued. The purpose of netting is reduction of receivables and payables, but we can never forget the register the invoices in order they could be used for accounting purposes. For these purposes would serve such a form (see Tab. 1).

Table1. Draft form for netting

\begin{tabular}{|c|c|c|}
\hline Receivables (Revenues) & \multicolumn{2}{|c|}{ Liabilites (Payments) } \\
\hline $\mathrm{YEN}=\mathrm{xxxx},-$ & \multicolumn{2}{|l|}{ YEN = xxxx ,- } \\
\hline USD Mexico = xxxx ,- & \multicolumn{2}{|l|}{ USD Mexico = xxxx ,- } \\
\hline USD USA $=$ xxxx,- & \multicolumn{2}{|c|}{ USD USA $=$ xxxx,-- } \\
\hline $\mathrm{EUR}=\mathrm{xxxx},-$ & \multicolumn{2}{|c|}{ EUR $=$ xxxx,-} \\
\hline \multicolumn{3}{|c|}{ Exchange rates (Last Thursday in a month) } \\
\hline Conversion rates & \multicolumn{2}{|c|}{ Rate for CZK } \\
\hline $\mathrm{CNY}$ & \multicolumn{2}{|c|}{ Number of units for $\mathrm{CNY}=\mathrm{xx},-$} \\
\hline USD & \multicolumn{2}{|c|}{ Number of units for USD = xx ,- } \\
\hline EUR & \multicolumn{2}{|c|}{ Number of units for EUR = xx ,- } \\
\hline \multicolumn{3}{|c|}{ Netting of the current month } \\
\hline Branch & Revenue (in CZK) & Payment (in CZK) \\
\hline Č́na & $\mathrm{xxxx},-$ & $\mathrm{xxxx},-$ \\
\hline Mexiko & xxxx,- & $\mathrm{xxxx},-$ \\
\hline USA & $\mathrm{XXXX},-$ & $\mathrm{xxxx},-$ \\
\hline Bulharsko & $\mathrm{xxxx},-$ & $\mathrm{xxxx},-$ \\
\hline
\end{tabular}

Source: Own elaboration, 2016

The proposal forms of netting shows, that we have all the requirements for availability to information that is needed for netting process, but also for accounting to have evidence of all the payments done in a specific time period. The form consists of revenues and payments. These items keep the amount in a specific currency in which the liability or receivable was created. As we move down in the form above, there are currency conversion rates on CZK. At the end of the form the netting calculation is carried out in the Czech currency. From the proposed form it is evident that the netting is bilateral. Company XY will therefore make netting between each branch separatelly. 


\section{The Proposed Model NetTing}

Model of the netting process will be described in the last three months in the calendar year 20XX. The point is to outline the process of the netting and compare it with the process of payments without netting. The author considers only the internal payments in this model. All the amounts that model works with were proposed by financial manager of the company to protect internal data, but also to match with the reality. Only then the proposed model will be applicable in the market environment. Transactions undertaken during the last three months of calendar year 20XX are as follows (see Tab. $2-6)$.

Table2. Transactions were carried out with the branch of China in 20XX

\begin{tabular}{|l|l|l|}
\hline \multirow{2}{*}{ Month } & Receivable (CNY) & Liability (CNY) \\
\hline \multirow{5}{*}{ Nover } & $315400,-$ & $228350,-$ \\
\cline { 2 - 3 } & $\mathrm{X}$ & $112358,-$ \\
\cline { 2 - 3 } & $\mathrm{X}$ & $269108,-$ \\
\hline \multirow{2}{*}{ December } & $211308,-$ & $149561,-$ \\
\hline & $52311,-$ & $38112,-$ \\
\cline { 2 - 3 } & $\mathrm{x}$ & $24743,-$ \\
\hline
\end{tabular}

Source: Own elaboration on the basis of consultation within the undertaking, 2016

Table3. Transactions were carried out with a branch in Mexico in 20XX

\begin{tabular}{|l|l|l|}
\hline Month & Receivable (USD) & Liability (USD) \\
\hline \multirow{5}{*}{ October } & 13250 & 11108 \\
\cline { 2 - 3 } & 11820 & 9312 \\
\cline { 2 - 3 } & 2312 & 3355 \\
\cline { 2 - 3 } & 2530 & 2816 \\
\hline \multirow{2}{*}{ November } & 9567 & 2312 \\
\cline { 2 - 3 } & $\mathrm{x}$ & 862 \\
\hline December & 5412 & 6874 \\
\hline
\end{tabular}

Source: Own elaboration on the basis of consultation within the undertaking, 2016

Table4. Transactions were carried out with the branch of the US in 20XX

\begin{tabular}{|l|l|l|}
\hline Month & Receivable (USD) & Liability (USD) \\
\hline October & 2930 & 1868 \\
\hline November & 1132 & 511 \\
\hline December & 1108 & 1978 \\
\hline
\end{tabular}

Source: Own elaboration on the basis of consultation within the undertaking, 2016

Table5. Transactions were carried out with a branch in Bulgaria in $20 X X$

\begin{tabular}{|l|l|l|}
\hline Month & Receivable (EUR) & Liability (EUR) \\
\hline October & 2974 & 2815 \\
\hline \multirow{3}{*}{ November } & 1254 & 3321 \\
\cline { 2 - 3 } & 2318 & 1413 \\
\hline \multirow{3}{*}{ eccember } & 869 & 1312 \\
\cline { 2 - 3 } & 6816 & 3957 \\
\cline { 2 - 3 } & 12869 & 13351 \\
\hline
\end{tabular}

Source: Own elaboration on the basis of consultation within the undertaking, 2016

Table6. Exchange rates

\begin{tabular}{|l|l|l|l|}
\hline Month/Currency & CNY & USD & EUR \\
\hline October & 3,598 & 22,00 & 27,725 \\
\hline November & 3,604 & 22,123 & 27,610 \\
\hline December & 3,617 & 22,473 & 27,610 \\
\hline
\end{tabular}

Source: Own processing, 2016

Now all the transactions will be fulfilled into the proposed form and netting process will be completed for each month. Netting process is described by the three following (Tab. 7 -9.) 
Netting Impact on a Corporate Finance Management

Table7. Netting model in October $20 X X$

\begin{tabular}{|c|c|c|}
\hline Receivables (Revenues) & \multicolumn{2}{|c|}{ Liabilities (Payments) } \\
\hline $\mathrm{YEN}=315400$ & \multicolumn{2}{|c|}{ YEN = 609816} \\
\hline USD Mexiko = 29912 & \multicolumn{2}{|c|}{ USD Mexico = 26591} \\
\hline USDUSA = 2930 & \multicolumn{2}{|c|}{ USDUSA = 1868} \\
\hline EUR = 2974 & \multicolumn{2}{|l|}{ EUR $=2815$} \\
\hline \multicolumn{3}{|c|}{ Exchange rates $31.10 .20 X X$} \\
\hline Conversion rates & \multicolumn{2}{|c|}{ Rates for CZK } \\
\hline CNY & \multicolumn{2}{|c|}{ Number of units for $\mathrm{CNY}=3,598$} \\
\hline USD & \multicolumn{2}{|c|}{ Number of units for USD $=22,00$} \\
\hline EUR & \multicolumn{2}{|c|}{ Number of units for EUR $=27,73$} \\
\hline \multicolumn{3}{|c|}{ Netting in October } \\
\hline Branch & Revenue (in CZK) & Payment (in CZK) \\
\hline Č́na & $\mathrm{x}$ & 1059309 \\
\hline Mexiko & 73062 & $\mathrm{X}$ \\
\hline USA & 23364 & $\mathrm{X}$ \\
\hline Bulharsko & 4409 & $\mathrm{X}$ \\
\hline
\end{tabular}

Source: Own processing, 2016

Table8. Netting model in November $20 X X$

\begin{tabular}{|c|c|c|}
\hline Receivables (Revenues) & \multicolumn{2}{|c|}{ Liabilites (Payments) } \\
\hline $\mathrm{YEN}=211308$ & \multicolumn{2}{|c|}{$\mathrm{YEN}=149561$} \\
\hline USD Mexiko $=9567$ & \multicolumn{2}{|l|}{ USD Mexico = 3173} \\
\hline USD USA = 1132 & \multicolumn{2}{|l|}{ USD USA $=511$} \\
\hline EUR = 3572 & \multicolumn{2}{|l|}{ EUR = 4734} \\
\hline \multicolumn{3}{|c|}{ Exchange rates 30.11.20XX } \\
\hline Conversion rates & \multicolumn{2}{|c|}{ Exchange rates for CZK } \\
\hline CNY & \multicolumn{2}{|c|}{ Number of units for $\mathrm{CNY}=3,60$} \\
\hline USD & \multicolumn{2}{|c|}{ Number of units for USD $=22,12$} \\
\hline EUR & \multicolumn{2}{|c|}{ Number of units for EUR $=27,61$} \\
\hline \multicolumn{3}{|c|}{ Netting in November } \\
\hline Branch & Revenue (in CZK) & Payment (in CZK) \\
\hline Čína & 222289 & $\mathrm{X}$ \\
\hline Mexiko & 141435 & $\mathrm{x}$ \\
\hline USA & 13737 & $\mathrm{x}$ \\
\hline Bulharsko & $\mathrm{X}$ & 32083 \\
\hline
\end{tabular}

Source: Own processing, 2016

Table9. Netting model in December 20XX

\begin{tabular}{|c|c|c|}
\hline Receivables (Revenues) & \multicolumn{2}{|c|}{ Liabilites (Payments) } \\
\hline $\mathrm{YEN}=52311$ & \multicolumn{2}{|c|}{$\mathrm{YEN}=62855$} \\
\hline USD Mexiko = 5412 & \multicolumn{2}{|c|}{ USD Mexico $=6874$} \\
\hline USD USA = 1108 & \multicolumn{2}{|c|}{ USD USA = 1978} \\
\hline $\mathrm{EUR}=20554$ & \multicolumn{2}{|l|}{ EUR $=18620$} \\
\hline \multicolumn{3}{|c|}{ Exchange rates 31.12.20XX } \\
\hline Conversion rates & \multicolumn{2}{|c|}{ Exchange rates for $\mathrm{CZK}$} \\
\hline CNY & \multicolumn{2}{|c|}{ Number of units for $\mathrm{CNY}=3,62$} \\
\hline USD & \multicolumn{2}{|c|}{ Number of units for USD $=22,47$} \\
\hline EUR & \multicolumn{2}{|c|}{ Number of units for EUR $=27,61$} \\
\hline \multicolumn{3}{|c|}{ Netting in December } \\
\hline Branch & Revenue (in CZK) & Payments (in CZK) \\
\hline Čína & $\mathrm{x}$ & 38169 \\
\hline Mexiko & $\mathrm{x}$ & 32851 \\
\hline USA & $\mathrm{X}$ & 19548 \\
\hline Bulharsko & 53397 & $\mathrm{X}$ \\
\hline
\end{tabular}

Source: Own processing, 2016 
Ing. Jiří Kronych et al.

\section{Evaluation of Proposed Netting}

All the pros and cons of proposed netting process will be evaluated in this chapter.

Table10. Pros and Cons of the proposed netting process

\begin{tabular}{|l|l|}
\hline Pros & Cons \\
\hline Payment reduction & Slowness \\
\hline Time saving & Payments for additional software \\
\hline Reduction of mismatch in financial planning & \\
\hline Clearing center not needed & \\
\hline Better Cash Flow & \\
\hline
\end{tabular}

Source: Own processing, 2016

In the following passage the individual advantages and disadvantages are zoomed and analyzed:

- Payment reduction - this advantage is the reduction in the number of payments that company would have realized if they did not use netting.

- Time saving - this advantage is related to a previous reduction of payments. The fewer payments are made, the less time relevant employes spend on.

- Reduction of mismatch in financial planning - company's management in the financial planning and analysis will not be swamped by the lot of information, but they will only operate with specific, information.

- Clearing center not needed - there is no need for the clearing center - a model case of netting, which the author propose, does not require the use of the clearing center. It is a bilateral netting when the company nett with each company separately. For the proposed model the clearing center is not needed, which is also related to the cost savings fact.

- Better cash flow - due to the fact of netting company may not realize the abundance of incoming and outgoing payments it improves monthly cash flow.The result that company can operates with larger amounts than without netting. It does not have to deal with redundant outgoing or incoming payments, but only solves netting amount. Furthermore, because the netting is moved to the end of the month, money has a longer time period for holding in a given month.

- Slowness - this aspect relates primarily due to the proposed method of bilateral netting. We can not say with certainty that this is a disadvantage. Anyway if if you compare the process of bilateral netting process without netting is a bilateral netting faster. But if we compare the bilateral netting with netting for help clearing center within the group and bilateral netting behind. Certain disadvantage in this respect is a bilateral netting nettování at the end of the month, which at first may seem complicated and time consuming.

\section{Conclusion}

From the proposed bilateral netting in a company is obvious, that the model brings to the company transparent system, that helps company reduce the transaction with other branches. The model does not need clearing center, but for the proper working of the model, it is needed to broaden the part of the company system.

Authors took into account all the pros and cons, that are described in the chapter 5. Netting model was proposed to fulfill the requirements of the company to be able to stay autonomus and independent on the mother company. Company can handle this model without support of the mother company and even without support of the other branches, so the anonimity criteria was fulfilled too.

The most important thing for the proposed netting model is to respect all the rules, that were set up and continous in netting system.

\section{ACKNOWLEDGMENT}

This paper was created within the science project SGS-2015-021 Development of Financial Management Approaches as a Tool for Corporate Value Growth. 


\section{REFERENCES}

[1] Brealey, R. A., Myers, S. C. a Allen, F., Teorie a praxe firemních financí. BizBooks, Brno. 1096 (2014).

[2] Cooper, R., Corporate treasury and cash management. Palgrave Macmillan, Hampshire. 415 (2004).

[3] Česká národní banka. Řízení rizik a kapitálové požadavky ve finančních sektorech. Retrieved from

http://www.cnb.cz/cs/verejnost/pro_media/clanky_rozhovory/media_2003/cl_03_030327a.html [2016, November 10]

[4] King, J. M., Bank and Brokerage Bank Office Procedures and Settlements. Global Professional Publishing. 193 (2000).

[5] Madura, J., International financial management. South-Western Cengage Learning, Mason. 703 (2012).

[6] Siddaiah, T., International Financial Management. Pearson Education, India. 450 (2010).

\section{AUTHORS` BIOGRAPHY}

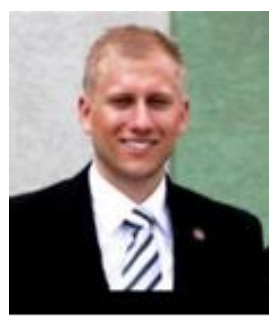

Ing. Jiř́ Kronych, Ph.D. student at the Department of Finance and Accounting, Faculty of Economics, University of West Bohemia, Czech Republic. Participated during studies in the program Erasmus in France, University Sup de Co Amiens. Before the graduation was a part of the exchange programme in Milwaukee, United states. The programme was focused on the economic aspects of the new evolution of the market. In parallel he has been working in several private companies in automotive industries as a financial controller.

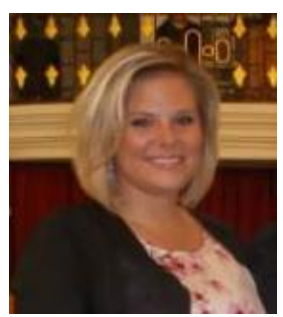

Ing. Andrea Malá, Ph.D. student at the Department of Finance and Accounting, Faculty of Economics, University of West Bohemia, Czech Republic. Participated during the studies in the exchange programme in Milwaukee, United states. The programme was focused on the economic aspects of the new evolution of the market. She he has been working as Account Manager in Renomia company.

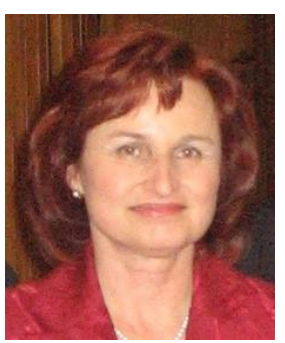

Prof. Ing. Lilia Dvořáková, CSc., Full-time professor at the Department of Finance and Accounting, Faculty of Economics, University of West Bohemia, Czech Republic. Chairman of Subject area board and supervisor in doctoral programme Economics and Management of the Faculty of Economics. Focus of research activities on performance measurement and management, financial and managerial accounting, controlling. 